\title{
Impact of COVID-19 on primary care visits: Lesson learnt from the early pandemic period
}

\author{
Sholahuddin Rhatomy, ${ }^{1,2^{*}}$ and Thomas Edison Prasetyo ${ }^{3,4}$
}

\author{
'Sport and Adult Reconstruction Division, Department of Orthopaedics and Traumatology, Dr Soeradji Tirtonegoro \\ General Hospital \\ ${ }^{2}$ Department of Surgery, Faculty of Medicine, Public Health, and Nursing, Universitas Gadjah Mada, Yogyakarta, Indonesia \\ ${ }^{3}$ Soeradji Tirtonegoro Sport and Research Unit, Dr Soeradji Tirtonegoro General Hospital, Klaten, Indonesia. \\ ${ }^{4}$ Internship Medical Doctor of Puskesmas Bayat, Klaten, Indonesia
}

\section{KEYWORDS}

Epidemiology study

COVID-19

Primary care
ABSTRACT In Indonesia, primary healthcare facilities play important roles in disease control and prevention. Changes in healthcare seeking behavior during the COVID-19 pandemic, especially to primary care, might have impacts to the overall public health status. This comparative epidemiology study aimed to investigate the changes of healthcare seeking behavior in primary care settings during the early pandemic period. Weekly number of visits to a primary healthcare facility in Klaten, Indonesia was examined from the $1^{\text {st }}$ week of 2018 -through the $25^{\text {th }}$ week of 2020. The selected period affected early by COVID-19 in 2020 was defined (early pandemic period) and compared to the same corresponding period in 2019 (comparison period). The total number of patient visits, number of visits by age, gender, clinical decisions, patient status and diagnostic categories were obtained, compared, and analyzed. Mean differences and prevalence ratio of a specific diagnostic category between the two periods were calculated. The lowest period was from weeks $14-21,2020$, which we identified as the early pandemic period. Comparing the early pandemic period to the comparison period, we found that there was $46.3 \%$ decrease of total number of visits. The decline was especially apparent for children aged 0-9 (71\%), females (46\%), registered patients (49\%), and outpatients (48\%). Most of diagnostic categories also saw declines. Unfortunately, patients with hypertension also saw notable decline in mean differences and prevalence ratio albeit not desirable. In conclusion, some declines in the number of visits were not desirable including decreasing hypertension visit. This trend might negatively impact public health status afterward. Proper countermeasures are needed to control the ongoing trend. Further studies regarding the impact of COVID-19 on treatment seeking behavior is needed to plan effective countermeasures.

(c) The Journal 2020. This article is distributed under a Creative Commons Attribution-ShareAlike 4.0 International license.

\section{Introduction}

Coronavirus disease 2019 (COVID-19) is a disease caused by the transmission of Severe Acute Respiratory Syndrome Coronavirus 2 (SARS-CoV-2). It was declared a pandemic by the World Health Organization (WHO) on March 11, 2020 and a national public health emergency by the President of Indonesia, Joko Widodo on March 31, 2020., As of July 12 , there have been 75,699 confirmed cases and

*Correspondence: doktergustomrhatomy@yahoo.com Sport and Adult Reconstruction Division, Department of Orthopaedics and Traumatology, Dr Soeradji Tirtonegoro General Hospital. Jl. Dr. Soeradji Tirtonegoro No.1, Dusun 1, Tegalyoso, Kec. Klaten Sel., Kabupaten Klaten, Jawa Tengah 57424
3,606 total deaths in Indonesia. ${ }^{3}$ These numbers are still increasing daily.

The transmission of SARS-CoV-2 is faster than the first coronavirus, the causal agent of Severe Acute Respiratory Syndrome (SARS), due to several reasons. Viral loads in the nose and throat were found to be higher for SARS-CoV-2. Additionally, infected people might show only few to no symptoms. This phenomenon was not observed in SARS, in which no reported transmission occurred before the development of symptoms. ${ }^{4-6}$ Bertolino et al.7 reported that COVID-19 symptoms were fever in $76-99 \%$ cases, cough in $70 \%$, shortness of breath $46 \%$, and $80 \%$ had other mild symptoms, although 
the authors stated that the data were obtained from a hospital setting. Therefore, the WHO has strongly advised the public to take several precautions including hand and respiratory hygiene, physical distancing, and staying home. ${ }^{8}$

As the number of confirmed cases increased exponentially, reports from USA ${ }^{9-11}$, Canada ${ }^{12}$, Norway $^{13}$, Italy ${ }^{14}$, Austria ${ }^{15}$, Greece ${ }^{16}$, Turkey ${ }^{17}$, India ${ }^{18,}$ and Hongkong ${ }^{19}$ suggested sharp declines in the number of patients looking for medical care, both in outpatient and emergency department (ED) settings. This has raised some concerns, especially when serious conditions such as stroke or acute coronary syndrome, also have decreased. ${ }^{12,15,18,19} \mathrm{~A}$ big data analysis was conducted by the Centers for Disease Control and Prevention (CDC-P), USA, comparing the number of visits to ED from a subset of hospitals in 47 states during the early pandemic period (week $14-17,2020$ ) to a comparison period (week 14$17,2019)$. They found that the number of visits for conditions including nonspecific chest pain and acute myocardial infarct decreased. This trend might suggest people tended to delay care for serious health issues, which eventually can lead to additional morbidity and mortality. It is important to note that, compared to the previous year, the number and ratio of visits for cardiac arrest and ventricular fibrillation increased. ${ }^{11}$ While most of the studies and reports focused on decline in ED visits, a study by Kutlu et al. ${ }^{17}$ addressed the effect in dermatology clinic setting. It was found that the number of outpatient dermatology clinic visits decreased significantly in the early period of COVID-19 outbreak. Interestingly, acne was still at the top of diagnoses before and during the pandemic despite severe warnings and enforcement of staying home. Irritant contact dermatitis also increased, suggesting improper use of hand hygiene. This epidemiological information is essential to synthesize accurate health messages to the public.

In Indonesia, primary healthcare facilities play important roles in disease control and prevention. The national health system encouraged the public to seek treatment in the primary care settings before further specialized care. This process is continuously monitored by the Social Security Administrator of Health (Badan Penyelenggara Jaminan Sosial
[BPJS] Kesehatan). Therefore, a large number of Indonesians depend on the primary care to receive their treatments. Changes in healthcare seeking behavior during this pandemic, especially to the primary care, might translate to changes of the overall public health status.

Our target population was from Bayat, Klaten, Central Java. According to latest official data from $2019^{20}$, Bayat had a total population of 65,148 within 18 subdistricts, with 1 public primary healthcare facility and 3 private clinics, 5 medical doctors, 22 midwives and 22 nurses. Majority of adults worked in agriculture or trading sectors. To date (July $8^{\text {th }}$, 2020), in Klaten regency, there were 167 cumulative confirmed COVID-19 cases. Among them, 133 have recovered, 27 were still in isolation, and 7 died. Bayat has contributed the highest number of cumulative cases. ${ }^{21}$ In order to decrease the transmission, the Klaten governor has taken some countermeasures such as continuous monitoring of cases, health promotions through social media, public announcements and restrictions. ${ }^{21}$

Currently, we found no epidemiological study in Indonesia which assessed the trends of healthcare facility visits during the pandemic. In this novel study, we aimed to investigate the changes of primary care visits in the early pandemic period. Further, we examined differences in age groups, gender, clinical decisions, patient status and the diagnostic categories. We hypothesized that there would be a decrease in the total number of visits, as well as decreases in each group.

\section{Method}

\subsection{Study design}

This study was a novel epidemiologic study investigating the total number of visits, number of visits by age, gender, clinical decisions, patient status and diagnostic categories in a public primary care facility (Pusat Kesehatan Masyarakat [Puskesmas]) at Bayat, Klaten City, Central Java, Indonesia. Data were collected retrospectively from the online integrated information management system (Sistem Informasi Manajemen Puskesmas [SIMPUS]) of Puskesmas Bayat from July, 10-13 ${ }^{\text {th }} 2020$. The online system is compulsory and widely used in Indonesian 
healthcare system using diagnostic codes from the International Classification of Diseases, $10^{\text {th }}$ revision (ICD-10).

\subsection{Data collection}

Weekly number of Puskesmas visits were retrospectively counted from the $1^{\text {st }}$ week of 2018 $25^{\text {th }}$ week of 2020. In our study, the first week of a year was defined as a full 7 days from the first Sunday. Hence, in 2018, the first week started at January $7^{\text {th }}$. We would then select a weekly timeframe with the lowest total number of visits in $\mathbf{2 0 2 0}$ (the early pandemic period) and compared it with the same weekly period in 2019. For this study, patients who receiving treatment outside the Puskesmas were excluded (e.g. home visits).

From the selected period, the number of visits from each patient age, gender, status (new or registered) and clinical decisions (outpatient, external or internal referral) were recorded. In addition, visits for specific diagnostic categories were compared using mean differences and prevalence ratios. The difference in mean visits per four weeks during the early pandemic and the comparison period was calculated for each diagnostic category as follows:

$$
\begin{gathered}
\text { Mean difference per four week }= \\
\text { visits in category (early pandemic period) - } \\
\text { visits in category (comparison period) } \\
\text { total week in the period }
\end{gathered}
$$

The prevalence ratio (PR) for each diagnostic category was calculated as follows:

$$
P R=\frac{\frac{\text { visits in category }}{\text { total visits }}(\text { in early pandemic period) }}{\frac{\text { visits in category }}{\text { total visits }}(\text { comparison period })}
$$

\subsection{Diagnostic categories}

SIMPUS could readily show 20 top diagnostic categories for a desired timeframe. As a novel study, we limited the analysis to these top categories during the selected timeframes. It was known that some diagnoses made by physicians could be inputted into one or more diagnostic categories or subcategories in the system. Any doubts regarding similar diagnostic categories were resolved by discussion with the coding officers and physicians of Puskesmas Bayat whether the clashing categories could be combined into one bigger category. If eligible, the combined categories were given a new label.

\subsection{Data management}

The data were all inputted, tabulated and analyzed using the SPSS 25.0 statistical system (IBM Corporation, USA).

\section{Result}

Figure 1 shows the weekly number of Puskesmas Bayat visits in years 2018, 2019 and 2020. As for year 2018 and 2019, the trend was linear. Note that the deep bottom of year 2018 (23 $3^{\text {rd }}$ week) and $2019\left(22^{\text {nd }}\right.$ week) was due to the Eid al-Fitr and national leave days.

In 2020, a strong downtrend occurred from the $12^{\text {th }}-13^{\text {th }}$ week of 2020 . In week 14 , the graph started to plateau, although a much weaker downtrend can still be seen until week 21 . The nadir was in weeks $17^{\text {th }}$ and $20^{\text {th }}$, each with the total of 282 visits per week. However, the decrease was greater in the $20^{\text {th }}$ week compared to last year (54.9\%). Afterward, the number of visits increased although until our most recent data at week 24 , it was still $29.9 \%$ below the corresponding week in 2019.

To quantify the early effects of COVID-19 on the number of Puskesmas visits, we defined an eightweek period in which the weekly numbers were at the lowest, which was week $14-21$ (March 29 - May 23, 2020). This "early pandemic period" was compared to the corresponding eight-week period in the previous year (March 31 - May 25, 2019). The early pandemic period saw a $46.3 \%$ decrease of overall visits compared to 2019 (2,727 vs. 5,074 visits).

Figure 2 breakdowns the visits by age, gender, final clinical decisions, and patient status. To summarize, all age group saw diminishing visits, especially in younger groups, which were children aged $0-9$ years $(71 \%)$, adolescents aged $10-19$ years (63\%), and young adults aged $20-44$ (50\%). Decrease 


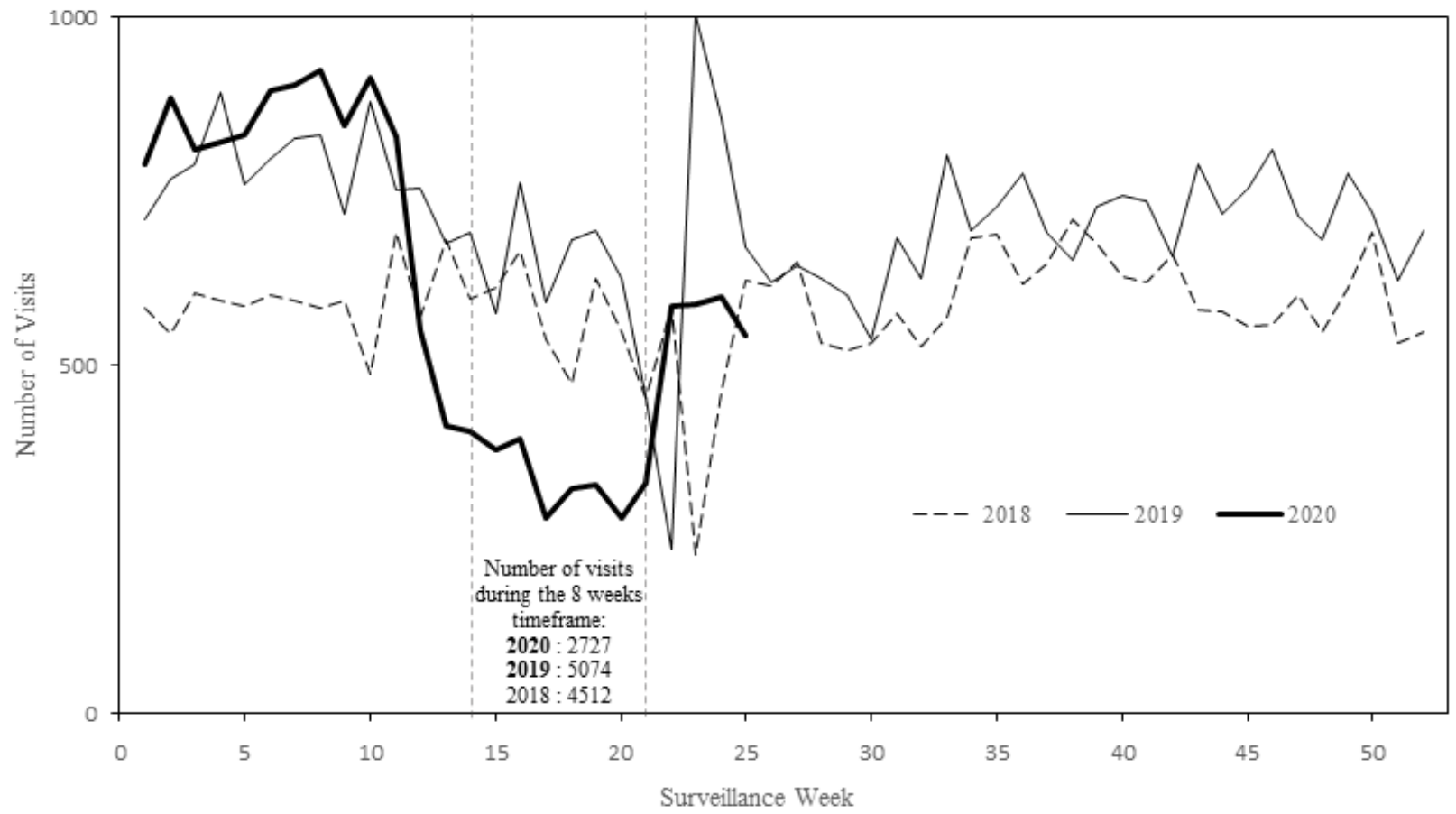

Figure 1. Weekly number of Puskesmas Bayat visits from January 4, 2018 to May 23, 2020. The vertical dashed lines delineate the eight-week periods, the early pandemic period (March 29 to May 23, 2020) and the comparison period (March 31 to May 25, 2019)
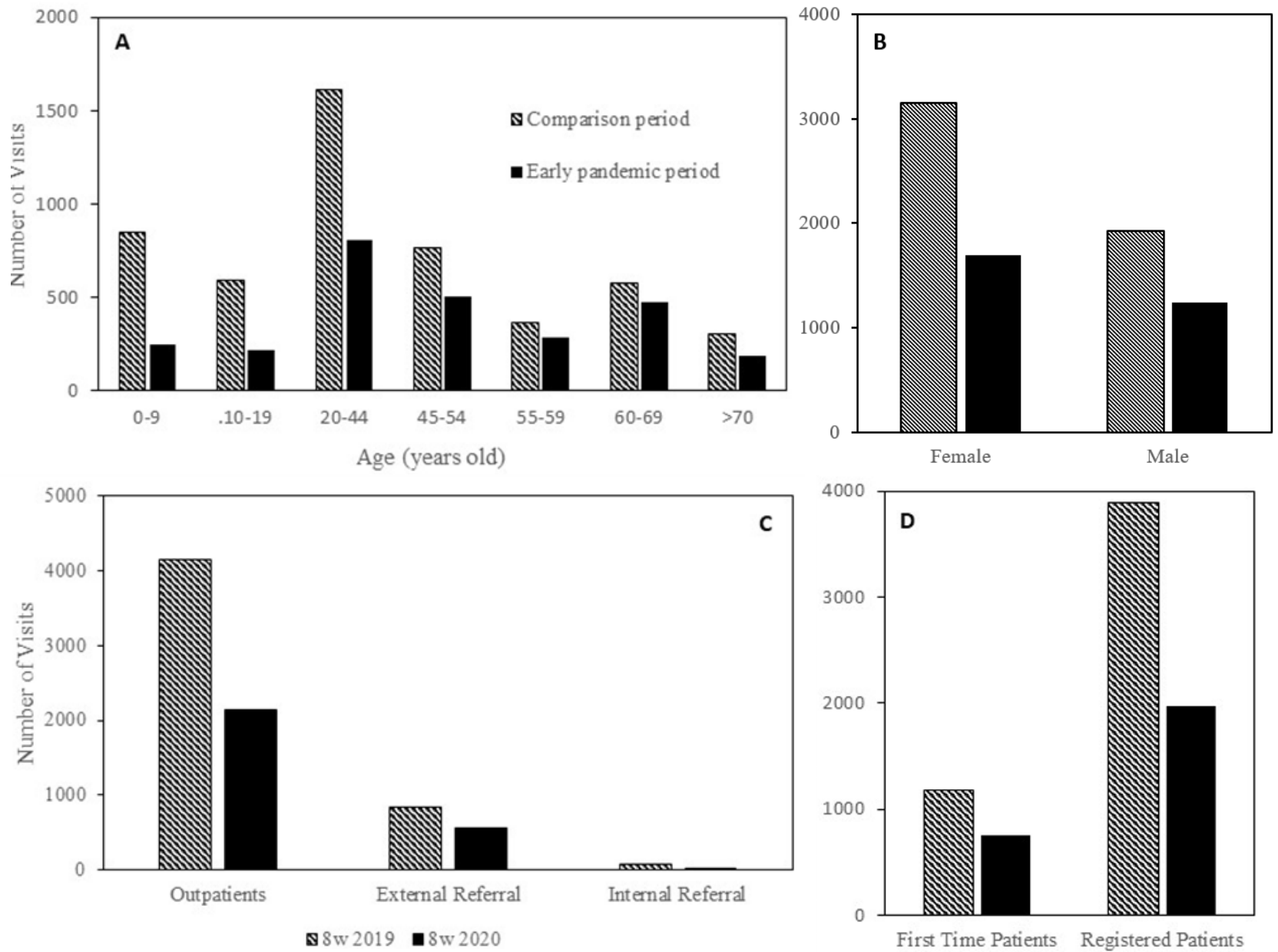

Figure 2. Puskesmas Bayat visits on March 29 - May 23, 2020 (early pandemic period) and March 31 - May 25, 2019 (comparison period) by age group (A), gender (B), final clinical decision (C), and patient status (D). The data are taken from SIMPUS. 
Table 1. Diagnostic categories adjustment process

\begin{tabular}{|c|c|c|c|c|c|c|}
\hline \multirow{2}{*}{ No. } & \multicolumn{4}{|c|}{ Similar or vague diagnostic categories } & \multirow{2}{*}{ Discussion result } & \multirow{2}{*}{$\begin{array}{l}\text { Adjusted } \\
\text { diagnostic } \\
\text { category }\end{array}$} \\
\hline & Category 1 & Category 2 & Category 3 & Category 4 & & \\
\hline 1 & $\begin{array}{l}\text { Essential } \\
\text { (primary) } \\
\text { hypertension }\end{array}$ & $\begin{array}{l}\text { Renovascular } \\
\text { hypertension }\end{array}$ & - & - & $\begin{array}{l}\text { Both were used for } \\
\text { the same diagnosis }\end{array}$ & $\begin{array}{l}\text { Essential } \\
\text { hypertension }\end{array}$ \\
\hline 2 & $\begin{array}{l}\text { Acute upper } \\
\text { respiratory } \\
\text { infection, } \\
\text { unspecified }\end{array}$ & $\begin{array}{l}\text { Acute } \\
\text { nasopharyngitis } \\
\text { [common cold] }\end{array}$ & - & - & $\begin{array}{l}\text { Both were used for } \\
\text { the same diagnosis }\end{array}$ & $\begin{array}{l}\text { Acute upper } \\
\text { respiratory } \\
\text { infection }\end{array}$ \\
\hline 3 & Dyspepsia & $\begin{array}{l}\text { Gastritis, } \\
\text { unspecified }\end{array}$ & Other gastritis & - & $\begin{array}{l}\text { Both were used for } \\
\text { the same diagnosis }\end{array}$ & $\begin{array}{l}\text { Discomfort } \\
\text { related to } \\
\text { stomach }\end{array}$ \\
\hline 4 & $\begin{array}{l}\text { Supervision } \\
\text { of normal first } \\
\text { pregnancy }\end{array}$ & $\begin{array}{l}\text { Antenatal } \\
\text { screening }\end{array}$ & - & - & $\begin{array}{l}\text { They were } \\
\text { combined because } \\
\text { it could be used } \\
\text { interchangeably }\end{array}$ & $\begin{array}{l}\text { Supervision of } \\
\text { pregnancy }\end{array}$ \\
\hline 5 & $\begin{array}{l}\text { Dermatitis, } \\
\text { unspecified }\end{array}$ & Other dermatitis & - & - & $\begin{array}{l}\text { Both were used for } \\
\text { the same diagnosis }\end{array}$ & Dermatitis \\
\hline 6 & $\begin{array}{l}\text { Need for } \\
\text { immunization } \\
\text { against } \\
\text { tuberculosis } \\
\text { [BCG] }\end{array}$ & $\begin{array}{l}\text { Need for } \\
\text { immunization } \\
\text { against measles } \\
\text { alone }\end{array}$ & $\begin{array}{l}\text { Need for } \\
\text { immunization } \\
\text { against other } \\
\text { combinations } \\
\text { of infectious } \\
\text { diseases }\end{array}$ & $\begin{array}{l}\text { Need for } \\
\text { immunization } \\
\text { against tetanus } \\
\text { alone }\end{array}$ & $\begin{array}{l}\text { These categories } \\
\text { were combined. }\end{array}$ & Immunization \\
\hline 7 & $\begin{array}{l}\text { General } \\
\text { examination and } \\
\text { investigation of } \\
\text { persons without } \\
\text { complaint } \\
\text { and reported } \\
\text { diagnosis }\end{array}$ & $\begin{array}{l}\text { General medical } \\
\text { examination }\end{array}$ & - & - & $\begin{array}{l}\text { Both were used for } \\
\text { the same diagnosis }\end{array}$ & $\begin{array}{l}\text { General } \\
\text { medical } \\
\text { examination }\end{array}$ \\
\hline 8 & $\begin{array}{l}\text { Fever, } \\
\text { unspecified }\end{array}$ & $\begin{array}{l}\text { Other specified } \\
\text { fever }\end{array}$ & - & - & $\begin{array}{l}\text { These categories } \\
\text { were combined }\end{array}$ & Fever \\
\hline 9 & $\begin{array}{l}\text { Counselling } \\
\text { related to } \\
\text { sexual attitude, } \\
\text { behavior and } \\
\text { orientation }\end{array}$ & - & - & - & $\begin{array}{l}\text { This was inputted } \\
\text { for patients seeking } \\
\text { counselling in } \\
\text { general, without } \\
\text { any medical } \\
\text { examination. }\end{array}$ & $\begin{array}{l}\text { Counselling in } \\
\text { general }\end{array}$ \\
\hline
\end{tabular}

was also seen in both genders. However, female visits showed more decline (46\%) than males (36\%). In the early pandemic period, visits of registered patients declined by $49 \%$, while new patients decreased by $37 \%$. As for final clinical decisions, the number of outpatients declined by $48 \%$, external referrals by $33 \%$ and internal referrals by $71 \%$.

Among the top 20 diagnostic categories in the included weeks of the two periods, there were some similar or vague categories. We discussed these potential biases with the officers and physicians and made adjustments. The adjustment process is shown in Table 1, and was followed by data analysis.

It was found that positive mean difference per four weeks only occurred in two diagnostic categories (Table 2.), immunization (mean increase 
Table 2. Mean difference of visit per four week and prevalence ratio for specific diagnostic category

\begin{tabular}{lll}
\hline Diagnostic category & Mean difference of visit per four & PR \\
\hline Acute upper respiratory infection & weeks & 0.39 \\
Myalgia & -619 & 0.69 \\
Essential Hypertension & -255 & 0.77 \\
Discomfort related to stomach & -230 & 0.90 \\
Headache & -135 & 0.99 \\
Cough & -98 & 0.52 \\
Fever & -92 & 0.81 \\
Supervision of pregnancy & -88 & 1.01 \\
Necrosis of pulp & -61 & 0.71 \\
Dermatitis & -49 & 1.29 \\
Diarrhea and gastroenteritis of presumed infectious origin & -37 & 0.88 \\
General medical examination & -31 & 1.37 \\
Non-insulin-dependent diabetes mellitus without complications & -4 & 1.54 \\
Counselling in general & 31,5 & 4,52 \\
Immunization & 41 & 5,04 \\
\hline Data are obtained from SIMPUS. The observed periods are March 29-May 23, 2020 (early pandemic period) and March 31-May 25, 2019 (comparison \\
period). PR = prevalence ratio. & &
\end{tabular}

in 41 visits per 4 week) and counselling in general (32). The sharpest declines were observed in acute respiratory infection (-619), myalgia (-255), essential hypertension (-230), discomfort related to stomach (-135), headache (-98), cough (-92) and fever $(-88)$. Other notable declines were supervision of pregnancy (-61), necrosis of pulp (-49), dermatitis (-37) and diarrhea and gastroenteritis of presumed infectious origin (-31).

During the early pandemic period, some increasing prevalence ratio included immunization ( $P R=5.04)$, counselling in general (4.52), non-insulindependent diabetes mellitus without complications (1.54), general medical examination (1.37) and dermatitis (1.29). On the other hand, diagnostic categories with the smallest proportion were seen in acute upper respiratory infection (0.39), cough (0.52), myalgia (0.69), necrosis of pulp (0.71), essential hypertension (0.77) and fever (0.81).

\section{Discussion}

Our primary finding was that during the selected 8-week interval, total number of visits were markedly lower than the same 8-week period in 2019. This finding was especially true for children, adolescents, young adults, females, previously registered patients, outpatients and internal referrals. In the
COVID-19 pandemic, people with mild conditions were discouraged from going to healthcare facilities to reduce transmission risk. The public were advised to seek treatment only if certain danger signs were apparent. ${ }^{11,17,22}$ In Bayat, Puskesmas used public posters which had messages discouraging visiting Puskesmas. The officers also told people not to come to any health facility unless it was really needed. During the early pandemic, all public programs were postponed except home visits to patients with severe disabilities, such as hemiplegic post-stroke patients. Puskesmas did not admit inpatients in this period.

We found that immunization and counselling activities increased compared to last year, suggesting that there might be growing concern about personal health during COVID-19 pandemic. Concordant to the finding, the number of general medical examinations were also more prevalent than the previous year (PR $=1.37$ ) as more people demanded health checkups.

The strongest decline was acute upper respiratory infection, both in mean difference and prevalence ratio. While the condition was generally accepted as a mild condition, this major decline might raise questions whether the public was reluctant to disclose information regarding their symptoms, as they had been continuously informed about the symptoms of COVID-19 including cough, fever, and shortness of breath. ${ }^{7}$ The argument was supported 
by the relatively sharp decline in cough and fever diagnostic category, both in mean difference and prevalence ratio. Further study is needed to address these reluctance issues.

Ideally, patients with milder conditions would be decreasing in frequency and/or prevalence ratio. On the other hand, several conditions should prompt the patient to seek treatment, including chronic conditions with the risk of worsening or complications, and acute life threatening conditions such as acute myocardial infarction, stroke, and severe shortness of breath. Thus, it was expected that these conditions would observe little to no change in the mean number of visits for but increasing prevalence ratio.

Hypertension and diabetes mellitus are known as common chronic diseases with complex pathophysiology that are faced daily in primary healthcare settings in Indonesia. If these conditions are not treated adequately, the intermediate or long term prognoses are poor. Moreover, both are significant comorbidities for many other diseases including COVID-19. ${ }^{23-25}$ In this study, we found that the number of diabetes mellitus visits had shown minimal decrease in the four week average, yet the prevalence ratio surged 1.54 times higher than the comparison period. This was desirable as it indicated that the patients were still willing to come for follow-ups. However, patients with hypertension did not seem to follow the ideal scenario, as the 4 weeks mean difference was negative $(-230)$ and the prevalence ratio was low (0.77). An actionable plan is therefore needed to control these trends.

Popular platforms such as Twitter, Instagram, Facebook and other social media have numerous roles in the pandemic. They are being used to monitor the progression of COVID-19 pandemic, to announce public policies and restrictions, to disseminate medical information or health advice, to deliver remote health care, and even to describe the geographic spread of COVID-19 which has been proven very effective..$^{26-31}$ In Klaten, the government used its official website and Instagram to deliver health messages, policies and monitor progressions. ${ }^{21}$ We suggest that they should design an appealing public health poster to encourage people with chronic diseases, specifically hypertension, to see their physicians with masks, face shield and appropriate hand hygiene. As the impact of COVID-19 and sociocultural characteristics of people are varied across regions, we presently need region-based studies for each region and identification of appropriate platforms to effectively influence people's health behavior.

Since our epidemiology study only reported data from primary care setting, acute life threatening conditions were not prevalent and were not recorded in the top 20 diagnosis categories. From the experience of one of the authors as a general practitioner, some patients who came to the ED after the early pandemic period suffered complications from their underlying chronic diseases, saying that they did not take the medicine they usually took, because they were too scared to go to healthcare facilities.

Other results were expectable. Myalgia, discomfort related to stomach, headache, necrosis of pulp, dermatitis, and diarrhea were mostly mild in primary care settings, thus the number of visits were declining. It is interesting to note that in spite of the declining number of visits, dermatitis was more prevalent than the comparison period $(P R=$ 1.29). Kutlu et al. ${ }^{17}$ had similar findings in Turkey, in which irritant contact dermatitis were in their top 5 diagnoses during the early pandemic period. They suggested that this was probably due to irritating disinfectants for hygiene.

Some results of our study were very similar to the $C D C$ recent big data report. ${ }^{11}$ The decline in children visits was the most pronounced, with $71 \%$ in our study versus $72 \%$ in CDC report. Although in other age groups, their study used different cutoffs, from their graphs we could visually conclude that the younger groups were decreasing the most. Very similar results could be seen in gender groups, for which male and female visits decreased by 36 and $46 \%$, respectively, in our study, as compared to 37 and $45 \%$ in the CDC report. These results implied that public reaction was probably similar despite differences in sociocultural systems.

Our study had several limitations. First, since this was a novel study, the total number of patients was small and therefore might not be representative of the 
overall population of Indonesia. Second, analysis of diagnostic categories relied on the top 20 diagnostic categories and might not be adequate to represent overall changes of mean visits and prevalence ratio. It is noteworthy that for specific diagnostic categories in this period of interest, we used mean difference per 4 weeks, because the magnitude of change per 1 week might be too small to appreciate in such a low volume setting. Third, the setting of our study was limited to a primary healthcare facility. We did not examine other settings such as secondary and tertiary facilities, or emergency departments.

\section{Conclusions}

We highlighted that patients with essential hypertension might be too discouraged to receive their usual treatments. In this circumstance, local governments should be advised to publish more public education promotions in social media regarding the need of routine treatment for patients with hypertension. Further studies with bigger data, different geographical areas, and healthcare settings are needed to spot trend changes and thus aid in planning the proper countermeasures for these changes.

\section{Conflict of interests}

The author(s) declared no potential conflict of interest with respect to the research, authorship, and/or publication of this article.

\section{References}

1. WHO Director-General's opening remarks at the media briefing on COVID-19 - 11 March 2020. https://www.who.int/dg/speeches/detail/whodirector-general-s-opening-remarks-at-themedia-briefing-on-covid-19---11-march-2020. Accessed May 24, 2020.

2. Jokowi declares COVID-19 health emergency, imposes large-scale social restrictions - National - The Jakarta Post. https://www.thejakartapost. com/news/2020/03/31/jokowi-declares-covid19-health-emergency-imposes-large-scalesocial-restrictions.html. Accessed July 13, 2020.

3. Situasi Terkini Perkembangan Coronavirus
Disease (COVID-19) 13 Juli $2020 »$ Info Infeksi Emerging Kementerian Kesehatan RI. https://covid19.kemkes.go.id/situasi-infeksiemerging/info-corona-virus/situasi-terkiniperkembangan-coronavirus-disease-covid-1913-juli-2020/\#.XwwBUSgzbIU. Accessed July 13, 2020.

4. Q\&A on coronaviruses (COVID-19). https:// www.who.int/emergencies/diseases/novelcoronavirus-2019/question-and-answers-hub/ q-a-detail/q-a-coronaviruses. Accessed May 24, 2020.

5. Yuki $K$, Fujiogi $M$, Koutsogiannaki $S$. COVID-19 pathophysiology: a review. Clin Immunol. 2020;215:108427. doi:10.1016/j. clim.2020.108427

6. SARS | Frequently Asked Questions | CDC. https://www.cdc.gov/sars/about/faq.html. Accessed May 24, 2020.

7. Bertolino L, Vitrone $M$, Durante-Mangoni $E$. Does this patient have COVID-19?: a practical guide for the internist. Intern Emerg Med. May 2020. doi:10.1007/s11739-020-02377-1

8. Advice for public. https://www.who.int/ emergencies/diseases/novel-coronavirus-2019/ advice-for-public. Accessed May 24, 2020.

9. Laura E. Wong; MD; PhD; Jessica E. Hawkins; MSEd; Simone Langness; Karen L. Murrell; Patricia Iris; MD \& Amanda Sammann; MPH. Where are all the patients? addressing COVID-19 fear to encourage sick patients to seek emergency care. NEJM Catal. 2020; (Figure 1):1-12. doi:https:// catalyst.nejm.org/doi/abs/10.1056/CAT.20.0193

10. Santoli JM, Lindley MC, DeSilva MB, et al. Effects of the COVID-19 pandemic on routine pediatric vaccine ordering and administration - United States, 2020. MMWR Morb Mortal Wkly Rep. 2020;69(19):591-593. doi:10.15585/mmwr. Hartnett KP, Kite-Powell A, DeVies J, et al. Impact of the COVID-19 pandemic on emergency department visits - United States, January 1, 2019-May 30, 2020. MMWR Morb Mortal Wkly Rep. 2020;69(23):699-704. doi:10.15585/mmwr. $\mathrm{mm} 6923 \mathrm{e} 1$

12. Bres Bullrich $M$, Fridman $S$, Mandzia JL, et 
al. COVID-19: Stroke admissions, emergency department visits, and prevention clinic referrals. Can J Neurol Sci / J Can des Sci Neurol. 2020:1-4. doi:10.1017/cjn.2020.101

13. Bjørnsen LP, Næss-Pleym LE, Dale J, Laugsand LE. Patient visits to an emergency department in anticipation of the COVID-19 pandemic. Tidsskr Nor Laegeforen. 2020;140(8). doi:10.4045/ tidsskr.20.0277

14. Mauro V, Lorenzo M, Paolo C, Sergio H. Treat all COVID 19-positive patients, but do not forget those negative with chronic diseases. Intern Emerg Med. 2020;(0123456789):3-6. doi:10.1007/s11739-020-02395-z

15. Metzler B, Siostrzonek P, Binder RK, Bauer A, Reinstadler SJ. Decline of acute coronary syndrome admissions in Austria since the outbreak of COVID-19: the pandemic response causes cardiac collateral damage. Eur Heart J. 2020;41(19):1852-1853. doi:10.1093/eurheartj/ ehaa314

16. Tsioufis K, Chrysohoou C, Kariori M, et al. The mystery of "missing" visits in an emergency cardiology department, in the era of COVID-19.; a time-series analysis in a tertiary Greek General Hospital. Clin Res Cardiol. 2020. doi:10.1007/ s00392-020-01682-1

17. Kutlu Ö, Günes R, Coerdt K, Metin A, Khachemoune A. Effect "stay-at-home" policy dermatology outpatient visits COVID - TURKEY. pdf. Dermatol Ther. 2020. doi:10.1111/ dth.13581

18. Kulkarni P, Mahadevappa M. COVID-19 pandemic and the reduction in ST- elevation myocardial infarction admissions. Postgr Med J. 2020;(May):2019-2020. doi:10.1136/ postgradmedj-2020-137895

19. Tam CCF, Cheung KS, Lam S, et al. Impact of Coronavirus Disease 2019 (COVID-19) outbreak on ST-segment-elevation myocardial infarction care in Hong Kong, China. Circ Cardiovasc Qual Outcomes. 2020;2019(April):2019-2021. doi:10.1161/CIRCOUTCOMES.120.006631 Awasi Corona Kab.Klaten. https://awasicorona. klatenkab.go.id/\#data. Accessed August 12, 2020.
20. Badan Pusat Statistik Kabupaten Klaten. https://klatenkab.bps.go.id/publication/2019/ 09/26/0241917e5c44384d314767aa/ kecamatan-bayat-dalam-angka-2019.html. Accessed August 12, 2020.

21. Awasi Corona Kab.Klaten. https://awasicorona. klatenkab.go.id/\#data. Accessed August 12, 2020.

22. Wabah Corona, Tunda ke Dokter dan Perhatikan Waktu yang Tepat. https://www.cnnindonesia.com/gayahidup/20200324140651-284-486469/wabahcorona-tunda-ke-dokter-dan-perhatikan-waktuyang-tepat. Accessed July 16, 2020.

23. Amraei R, Rahimi N. COVID-19, Reninangiotensin system and endothelial dysfunction. Cells. 2020;9(7):1-18. doi:10.3390/cells9071652

24. Saxena T, Ali AO, Saxena M. Pathophysiology of essential hypertension: an update. Expert Rev Cardiovasc Ther. 2018;16(12):879-887. doi:10.1 080/14779072.2018.1540301

25. Williams DM, Nawaz A, Evans M. Diabetes and novel coronavirus infection: implications for treatment. Diabetes Ther. 2020. doi:10.1007/ s13300-020-00858-2

26. Bisanzio D, Kraemer MUG, Brewer T, Brownstein JS, Reithinger R. Geolocated Twitter social media data to describe the geographic spread of SARSCoV-2. J Travel Med. July 2020. doi:10.1093/jtm/ taaa120

27. Basch $\mathrm{CH}$, Hillyer GC, Jaime C. COVID-19 on TikTok: harnessing an emerging social media platform to convey important public health messages. Int J Adolesc Med Health. August 2020. doi:10.1515/ijamh-2020-0111

28. Nesbitt C, Rath L, Yeh WZ, et al. MSCOVID19: using social media to achieve rapid dissemination of health information. Mult Scler Relat Disord. 2020;45. doi:10.1016/j.msard.2020.102338

29. González-Padilla DA, Tortolero-Blanco L. Social media influence in the COVID-19 Pandemic. Int Braz J Urol. 2020;46(suppl.1):120-124. doi:10.1590/S1677-5538.IBJU.2020.S121

30. Samy M, Abdelmalak R, Ahmed A, Kelada M. Social media as a source of medical information 
during COVID-19. Med Educ Online. 2020;25(1). ～- Worldometer. https://www.worldometers. doi:10.1080/10872981.2020.1791467 info/coronavirus/coronavirus-age-sex-

31. Coronavirus Age, Sex, Demographics (COVID-19) demographics/. Accessed May 26, 2020. 